\title{
Students' English Writing Process and Problems: A Case Study at Hamzanwadi University
}

\author{
Siti Maysuroh, Lalu Ilham Maryadi, Supiani \\ Study Program of English Language Education, Hamzanwadi University
}

\begin{abstract}
Writing is a very crucial skill in teaching and learning English as a Foreign Language (EFL). However, many students especially in Indonesia regarded this skill as the most complex task to complete, even for university students. Thus, the aim of this study was to describe the process of teaching writing in the classroom as well as to identify the students' writing problemsand to find out the factors which cause them. Thestudy was conducted in the second semester of English language program of Hamzanwadi University in academic year 20162017. The participants of this study consisted of 10 students selected using purposesful sampling technique. The research method used was a case study approach. In addition, in order to collect the data in the field, the researcher used some instruments; observation, interview, document and records.In addition, to ensure the trustworhiness of the data, the researcher followed some criteria adapted by Lincoln and Guba (1985), namely credibility (truth), dependability (consistency), transferability (applicability), and confirmability (Neutrality). The findings reveal that the students were taught using process approach in which the students were encouraged to learn writing throught some processes namely prewriting, drafting, revising, editing, and publishing. The researcher found that the students have various problems in their writing; mostly grammatical problems, word choice problems, and mechanical problems. They might be caused by some factors; lack practice, low motivation, and also time allocation.
\end{abstract}

\section{Introduction}

Vency H. J \& Ramganesh E. (2013) as cited in Sajid \& Siddiqui (2015) state that English language is widely recognized as a global communication linking the peoples of different continents for trade, commerce, and education etc. In accordance with the previous statement, Harmer (2002, p.2) also states that English will remain dominant among world languages and remain a vital linguistic tool for many business people, academicians, tourists 
and citizens of the world who wish to communicate easily across nationalities for many years to come.

Considering how important English nowadays, it becomes one of the compulsory subjects taught around the world whether as a second language (ESL) or a foreign language (EFL). In Indonesia itself, English is considered as the first foreign language taught from the primary schools up to university. The teaching of English as a foreign language in Indonesia is intended to cover the four language skills, namely reading, speaking, listening, and writing.

One of the skills needed to emphasize in teaching and learning a foreign language is writing skill. According to Hamp \& Heasly (2006, p.2) in Imane (2015), beyond the four vital language skills in the language process, competent writing is frequently accepted as being the last language skill to be acquired for native speakers of the language as well as for foreign/second language learners. However, writing is often neglected in the early graders, even though data consistenly show many students struggle in this area. (White \& Hall, 2014 in Ariyanti, 2016). As a consequence, it becomes a complicated task to do, even for a university student. Likewise, Grabe \& Kaplan (1996, p.6) as cited in Alfaki (2015) think that since writing does not come naturally but rather gained through continuous effort and much practice, it becomes a complex skill. Similarly on the difficulty of writing skill, Abu (2001, p.30) in Alfaki (2015) states that writing is a difficult skill for native speakers and non-native speakers alike because writers must balance multiple issues of content, organization, purpose, audience, vocabulary, punctuation, spelling, and mechanism.

Therefore, Emmons (2013) in Younes \& Albalawi (2015) emphasizes that writing is a basic skill that needs to be mastered by all English language major students. In fact, usually teachers focus more on teaching spoken language as well as reading and put little emphasis on teaching writing. They argue that teaching writing consumes time and can be problematic especially for disorganized students (Ramadani, 2014). However, we have to realize that writing is, once again, not a spontaneous skill. To be good in writing may take a long process and require hard work.

At Hamzanwadi University, especially in English Study Program, writing is one of courses that must be taken by every student without neglecting other language skills. It is in line with the opinion of Mohammad \& Hazarika (2016) that all the skills are equally important in a language but writing becomes more important in academic discipline because it is one of the most important means to examine the performance of students in their respective fields of study. Bjork \& Raisanen (1997, in Javin \& Umer, 2014, p.164) as cited in Mohammad \& Hazarika (2016) also argue that "we highlight the importance of writing in all university curricula not only because of its immediate practical application, i.e. as an isolated skill or ability, but because we believe that, from a broader perspective, writing is a thinking tool. It is a tool for language development, for critical thinking and, extension for learning in all disciplines". Furthermore, writing is often the factor which decides whether a students is 
succesful at university or not. A students' ability to master seminar papers,reports and exams determines whether a student will be succesful at university. (Piršl, piršl, and Kesić, 2011). As a consequence, this course has become the focus and concern of the study program in recent year.

In English Study program of Hamzanwadi University, this course is devided into three kinds, namely; (1) Writing for General Communication (taught in the second semester), (2) Writing for Academic Communication (taught in the third semester); and (3) Writing in Professional Context (taught in the fifth semester). Dealing with the subject of this study, the researcher focuses on the students learning Writing for General Communication in which this course is expected to develop the students' ability to write good English sentences; sentence building in all genres of English texts; descriptive, recount, narrative, process, and expository types of paragraph; The materials refer to the principles of sentence construction, sentence combination, sentence connectors, linking words, the variety of sources where ideas come from, main ideas and topic sentence, supporting details, concepts of paragraph and paragraph development. (Cited from English Study Program of HamzanwadiUniversity's curriculum, 2016).

However, a lot of problems dealing with EFL students' writing skill havebeen revealed in many studies. In Indonesia where English is treated as a foreign language, writing is, again, a complex task. Kuntjara (2004) as cited by Ariyanti points out that English tented to be taught mostly on grammar and reading, so that is why Indonesian students who study abroad face difficulties in terms of writing and oral communication.

Referring to the above theories and study, theresearcher wantedtoknowmore deeply about students'English writing process as well as to provide a brief overview of the problems encountered by the students of the second semester of Hamzanwadi University in academic year 2016-2017 and also the factors that may cause them. Therefore, the following research questions were formulated:

(1) How is the process of writing in the classroom?

(2) What are the commontypes of writing problems among the second semester students of English study program of Hamzanwadi University in the academic year 2016-2017?

(3) What are the possible factors that cause the students' problems in writing

\section{Method}

\subsection{Participant of the Study}

The selection of the participants in qualitative study is based on non-probability sampling where the researcher selects individuals because "they are available, convenient, and represent some characteristics the investigator seeks to study". Creswell (2012, p.145) in Abas (2016). 
For this study, the participantswere selected using purposeful sampling based on some considerations from the researchers. Thus, 10 students from the second semester students of Hamzanwadi University in the academic year 2016-2017wereselected to be the sample of this study.

\subsection{Data Collection}

\subsubsection{Instrument of the Study}

In collecting data, the main instrument is the researchers themself assisted with other instruments, those are observation, semi-structured interview, document and records. Writing samples alsohave been collected from students' task to analyze the actual problems students face in writing class.

\subsubsection{Techniques of Collecting Data}

In collecting data, the researcher conducted some techniques:

a. Observation

Here the researchers observed writing class to know the process of teaching writing

b. Interview

To get information more deeply, the researcher conducted a semi-structured interview (a series of open ended questions based on the topics that the researcher wants to cover ) with the students.

c. Documents and records

Every data or information such as interview record, students' writing task taken in the field were analyzed to be a report.

\subsubsection{Data Analysis}

For the data analysis, result of observation and interview was analyzed descriptively. In this case, the procedure of data analysis applied follows the procedures proposed by Miles and Huberman (1994:10-11) consisting of data reduction, data display, and conclusion drawing.

\subsubsection{Trustworthiness}

To ensure that this case study is accurate, the researcher takes the following criteria of trustworhiness promoted by Lincoln and Guba (1985) as cited in Billups (2014), namely:

(1) Credibility (truth): Are the qualitative findings believable? Do the findings appear truthful, capturing a holistic representation of the phenomenon under exploration?

(2) Dependability (consistency): Are the findings stable and consistent over time and across condition? Would the same data collection methods yield the same or similar result?

(3) Transferability (applicability): Are these findings comparable? Here, Lincoln and Guba (1985) note that, 'by describing a phenomenon in sufficient detail, one can begin to 
evaluate the extent to which the conclusions drawn are transferable to other times, settings, situation, and people.

(4) Confirmability (Neutrality): Are the findings accurate?. Here, there are two of the most commonly applied strategies include audit trails and reflexivity. Audit trails are likened to a research study blueprint, outlining detailed procedural records maintained by the primary researcher. This blueprint is accessible to an external researcher so s/he can attemp replication; if a study can replicated with similar results, confirmability is strengthened. Meanwhile, Reflexivityis the incorporation of the researcher's background, knowledge, bias, methodology, and perspective superimposed onto astudy. In other words, to what extent has the researcher worked to neutralize his or her own bias, motivation or interest as findings are reported.

\section{Results and discussion}

\subsection{Students' English Writing Process}

The result of observation revealed that the lecturer typically focused on a process approach in the teaching and learning writing process.This kind of process approach includes a number of steps; pre-writing, drafting, revising, editing, and publishing. Alfaki (2015) argues that the process approach to writing focuses on the composing process of writing instead of on the final products.Here, the lecturer guided the students to practice their English in written form through the following steps.

3.1.1 Pre-writing: inthis stage, the students were given some topics, and then the lecturer activated students' previous knowledge through brainstorming. In this proccess, the lecturer also explained to the students about the vocabulary and grammatical structures relevant to the topic they were interested in or had many ideas on.

3.1.2 Drafting: after they got some topics, the lecturer asked them to write down their main ideas and also arranged the supporting sentences which later can be developed into the whole paragraph

3.1.3 Revising: in this stage, the students combined all main ideas into paragraphs and explored them more deeply.

3.1.4 Editing: in the process of editing, the students were asked to check and correct the spelling, punctuation, and grammar of their own writing

3.1.5 Publishing: after they have revised their own writing, they can publish them. In this process, the lecturer asked the students to share their writing to their classmates and check it colaboratively with the lecturer.In addition, they were also asked to put their writing on wall magazine of the English Language Program. 


\subsection{Students' English Writing Problems}

The results showed that the participants had difficulties mostly in some aspects; grammatical problems, word choice problems, and mechanical problems.

\subsubsection{Grammatical problems}

The results of the study indicated that the students have problems mostly related to grammar. Kharma (1987)in Melese (2007, p.12) in Alfaki (2015) states that the students have problems with subject verb agreements, pronoun references, and connectors. It is in line with the finding of the study that some of the students were unable to use correct verb form in their writing related to the same matter as described below.

Table1

Examplesof grammatical problems

\begin{tabular}{|c|c|}
\hline Text & Correction \\
\hline 1. Him hobby is reading book & it should be his hobby \\
\hline $\begin{array}{l}\text { 2. You could be practices with tourism to } \\
\text { improve your English }\end{array}$ & it should be you can practice with the tourists \\
\hline 3. Now he live in Sakra & It should be he lives \\
\hline 4. He does not has.... & it should be he does not have \\
\hline 5. He is study at Hamzanwadi University & it should be he studies/is studying \\
\hline 6. It famous & it should be it is famous \\
\hline 7. People usually playing football & it should be usually play \\
\hline 8. His future plan is want to be a master of.. & it should be is to be... (want is ommitted) \\
\hline 9. How to be speaking very well & it should be how to speak very well \\
\hline $\begin{array}{l}\text { 10. In this Hamzanwadi University has } \\
\text { parking area }\end{array}$ & it should be Hamzanwadi University has... \\
\hline
\end{tabular}

\subsubsection{Word Choice Problems}

Table 2

Examples of word choice problem

Text Correction

1. Beautiful of this water fall is... it should be the beauty of

2. Many tourism and people

3. Many people visited in there because the beauty place

it should be many tourists and people

it should bevisited this place because of the beauty of it.

4. After that you go to Gili Trawarangan It should be using boat use to boat

3.2.3 Mechanical Problems

(1) Spelling 
Table 3

Examples of spelling problems

\begin{tabular}{|l|l|}
\hline \multicolumn{1}{|c|}{ Text } & \multicolumn{1}{c|}{ Correction } \\
\hline 1. He is a lider & it should be leader \\
2. He has browen eyes & it should be brown \\
3. Mawun beach it so clean & it should be is \\
4. You must by ticket & it should be you must buy \\
5. It has pacility & it should be it has facilities \\
6. He is realy funny & it should be really \\
7. Sometimes he fill that.. & it should be sometimes he feels that... \\
\hline
\end{tabular}

(2) Capitalization

Students' errors in capitalizationcan be exemplified as follows:

Table 4

Examples of capitalization problems

\begin{tabular}{lll}
\hline \multicolumn{1}{c}{ Text } & \multicolumn{1}{c}{ Correction } \\
\hline 1. At kute beach & it should be Kute \\
2. master of english... & it should be English \\
3. before you arrive to gili trawangan & it should be at Gili Trawangan
\end{tabular}

(3) Punctuation

Students' errors in punctuationcan be exemplified as follows:

Table 5

Examples of punctuation problems

Text Correction

1. I have a friend his name is $\mathrm{R}$, he is from it should be full stop after I have a friend Sakra, and Sakra.

2. Firstly I would like to tell you.. It should be firstly, i would like to..

3. He comes from Pademare a small town in.. It should be comma after Pademare

4. Thank's It should be thanks

\subsection{Factors which may cause the problems}

It is important to describe some factors contributing to the problems encontered by the students in their writing class. Based on the result of the study, it revealed that students' problems in writing may be caused by some following factors:

3.3.1 Lackpractice

As we have earlier mentioned that writing is regarded as the most complex skill. As the consequence, it needs much practice and continuous effort for both the teachers and students. 
In fact, the finding showed that the students practiced writing rarely. They also spent little time for studying writing at home. As the result, the students felt difficult to explore their ideas in written form.

\subsubsection{Low motivation}

Most of the students seemed to write for completing their task not for the sake of writing itself. They were not motivated to write as they considered it very difficult to do. This lack of interest and willingness may be one of the causes of the problems in writing

\subsubsection{Time allocation}

Another factor that contributes to students' problem was because the process of writing demanded time not only to write the text, but also to think, revise, etc. So that is why, the students could not finish it in the classroom as the time was over. For this reason, the lecturer gave chance to the students to continue their writing at home. However, the students did not complete their task more perfectly as they were given extra time.

\section{Conclusion}

On the basis of the results, some answers of the research questions can be concluded as follows:

1. In teaching writing for general communication for the second semester of Hamzanwady University, the lecturer applied process approach which involves some steps namely prewriting, drafting, revising, editing, and publishing

2. During the process of teaching and learning writing, some problems were found mostly on some aspects; grammatical problems including subject-verb agreement and combining sentences together to make a coherent paragraph, inappropriate choice of words or vocabularies, and mechanical problems including spelling, punctuation, and capitalizations.

3. Factors which might cause the problems are:lack practice, low motivation, and also time allocation.

\section{References}

Alves, Anable Reis. (2008). Process Writing. Module. Retrieved from http://www.birmingham.ac.uk/Documents/collegeartslaw/cels/essays/languageteaching/AReisAlvesProcessWritingLTM.pdf

Alfaki, Dr. Ibrahim Mohamed. (2015). University Students' English Writing Problems: Diagnosis and Remedy. International Journal of English Language Teaching Vol.3, No.3, PP.40-52. Retrieved from http://www.eajournals.org/wp-content/uploads/UniversityStudents----English-Writing-Problems-Diagnosis-and-Remedy.pdf 
Billups, F. (2014). The Quest for Rigor in Qualitative Studies: Strategies for Institutional Researchers.

Article.Retrieved

from

http://admin.airweb.org/eAIR/specialfeatures/Documents/ArticleFBillups.pdf

Graham, Steven. (2008). Effective Writing Instruction for All Students. Renaissance Learning, Inc. USA. Retrieved from doc.renlearn.com/KMNet/R004250923GJCF33.pdf

Harmer, J. 2002. The Practice of English Language Teaching. Harlow, Essex: Longman.

Huy, N. T. (2015). Problems affecting learning writing skill of grade 11 at thong linh high school. Asian Journal of Educational Research Vol,3(2). Retrieved from http://www.multidisciplinaryjournals.com/wp-content/uploads/ 2015/03/ PROBLEMSAFFECTING-LEARNING-WRITING-SKILL-OF-GRADE-11.pdf

Imane, Belhabeb. (2015). Difficulties Encountered by Students in Learning the Productive Skills in EFL Classroom and the Relationship between Speaking and Writing: Case of First Year LMD Students at Abou Bekr-Belkaid (Doctoral dissertation). retrieved from http://dspace.univ-tlemcen.dz/bitstream/112/7856/1/belhabib-imane.pdf

Javed, Muhammad., Juan, Wu Xiao., \& Nazli, Saima. (2013). A Study of Students' Assesment in Writing Skills of the English Language. International Journal of Instruction Vol.6 No.2. Retrieved from http://www.e-iji.net/dosyalar/iji_2013_2_9.pdf

Mohammad, Taj \& Hazarika, Zoheb. (2016). Difficulties of Learning EFL in KSA: Writing Skills in Context. International Jurnal of English Linguistics; Vol.6, No.3;2016. Retrieved from http://www.ccsenet.org/journal/index.php/ijel/article/viewFile/60143/32267

Mukminin, Amirul., Ali, Raden Muhammad., \& Ashari, Muhammad Jaya Fadloan (2015). Voices from Within: Student Teachers' Experiences in English Academic Writing Socialization at OneIndoneisan Teacher Training Program. The Qualitative Report Vol.20, Number 9, Article 2, 1394-1407 retrieved from http://www.novw.edu/ssss/QR/QR20/9/mukminin2.pdf

Piršl, Danica., Piršl, Tea.,\& Kesić, Dalibor. (2011).Writing Skills at University Level. Short Scientific Paper on Sport Logia 2011, 7(1), 69-72. Retrieved from www.sportlogia.com/no3engl/8.pdf

Ramadani, Istianah. (2014). Needs Analysis of Indonesian Freshmen's Writing at University of Indonesia: Problems and Solution. The 61st TEFLIN International Conference Journal. Retrieved from https://eprints.uns.ac.id/26261

Tahvildar, Zohreh \& Zade, Ali Emamjome. (2013). Evaluation of Writing Skill and Levels of Difficulty. Journal of Academic and Applied Studies Vol.3 (9) September 2013, pp. 53 63. Retrieved from www.academians.org

Yi, Jyi-yeon. (2009). Defining writing ability for classroom writing assessment in high schools. Journal of Pan-Pacific Association of Applied Linguistics, 13(1), 53-69

Younes, Zuhour Bani \& Albalawi, Fatima Salamh. (2015). Exploring the Most Common Types of Writing Problems Among English Language and Translation Major Sophomore 
Femal Students at Tabuk University. Asian Journal of Basic and Applied Sciences Vol, 3 No.2 retrieved from http://www.multidisciplinaryjournals.com/wpcontent/uploads/2016/03/FULL-PAPER-EXPLORING-THE-MOST-COMMONTYPES-OF-WRITING-PROBLEMS.pdf 